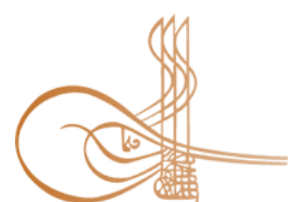

www.turkishstudies.net/language

\section{Turkish Studies - Language and Literature}

eISSN: 2667-5641

Research Article / Araştırma Makalesi

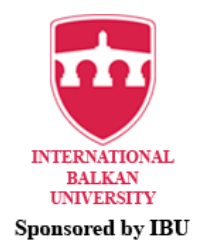

Sponsored by IBU

\title{
20. Yüzyıl Romanında Görülememek ve Tutunamamak: Oğuz Atay'ın Tutunamayanlar ve Ralph Ellison'un Görülmeyen Adam Adlı Eserlerinde Yabancılaşma Kavramının Karşılaştırılması
}

\author{
Invisibility and Disconnectedness in the Twentieth Century Novel: The Comparative Analysis of \\ the Concept of Alienation in Oğuz Atay's The Disconnected and Ralph Ellison's Invisible Man
}

\author{
Esin Kumlu*
}

\begin{abstract}
Regardless of time, place and social differences, the concept of alienation, as a part of social life, has been regarded as a universal theme. As literature is inherently the reflection of social life, the concept of alienation has become an intersection point of literary works. In relation, Oğuz Atay's The Disconnected (1972) and Ralph Ellison's Invisible Man (1952) address the concept of alienation through the portrayal of the spiritual journey of the universal lonely individual from the perspectives of Turkish and American cultures. In both works, in order to encounter and overcome their alienation, the main characters create a common space through the methods they develop. While, Atay sheds light upon the alienated individual via using disconnection as a motif, Ellison addresses the alienated individual in American society through invisibility. It is at this point that the characters of Atay, Turgut Özben and Selim Işık, who are sentenced to mental exile, literally coincide with the Invisible Man who is sentenced to a bodily exile. At the end of their stories, the characters, who reflect different geographies, manage to get out of their state of alienation from the society and their inner self's thanks to the strategies they develop. Their stories might be read as a passive resistance and can be analyzed by focusing on the web of images; rebirth, alienation and the end of exile to illuminate the story of the alienated individual. In this study, the concept of alienation is analyzed in relation with the themes 'disconnection' and 'invisibility' in plural investigation method via comparative literature within the frame of Hegel's concept of alienation and his master-slave dialectic. The study explores the commonalities and differences between the two texts considering the alienation processes of the protagonists and the strategies they construct in order to overcome their alienated bodies and identities.
\end{abstract}

Structured Abstract: Mathew Arnold in his Inaugural Lecture at Oxford in 1857 posits the view that "Everywhere there is connection, everywhere there is illustration. No single event, no single literature is adequately comprehended except in relation to other events, to other literatures." As underlined by Arnold, the connectedness of literary works provides a fruitful source for the academy. In the modern world, where globalization stands at the center of social life, that is the reason why comparative literature has gained a new momentum across the literary circle. As underlined by Henry Remak:

\footnotetext{
${ }^{*}$ Dr. Öğr. Üyesi, Dokuz Eylül Üniversitesi Buca Eğitim Fakültesi, Yabancı Diller Eğitimi Bölümü Asst. Prof. Dr. Dokuz Eylul University, Buca Faculty of Education, Department of Foreign Language Education ORCID 0000-0002-6884-6382

esinkumlu@yahoo.com

Cite as/ Atıf: Kumlu, E. (2020). 20. Yüzyıl romanında görülememek ve tutunamamak: Oğuz Atay'ın Tutunamayanlar ve Ralph Ellison'un Görülmeyen Adam adlı eserlerinde yabancılaşma kavramının karşılaştırılması. Turkish StudiesLanguage, 15(3), 1349-1367. https://dx.doi.org/10.47845/TurkishStudies.43800

Received/Geliş: 27 May/Mayıs 2020

Accepted/Kabul: 15 September/Eylül 2020

Copyright C INTAC LTD, Turkey
} 
Comparative literature is the study of literature beyond the confines of one particular country, and the study of the relationships between literature on the one hand, and other areas of knowledge and belief, such as the arts (e.g. painting, sculpture, architecture, music), philosophy, history, the social sciences (e.g. politics, economics, sociology), the sciences, religion, etc., on the others and the comparison of literature with other spheres of human expression. (1961: 3)

Comparative literature promotes the ability to understand others, how they feel and act under the same or different circumstances from different parts of the world. It helps to develop an awareness to understand the other therefore, increases the capacity for tolerance and respect towards others. In Turkey, comparative literature studies has gained popularity thanks to the academic departments in the universities.

The aim of this study is the comparative analysis of the concept of alienation in Oğuz Atay's The Disconnected from Turkish literature and Ralph Ellison's Invisible Man from American literature. As a universal term, alienation will be analyzed from the perspective of Hegel's notion of alienation within the borders of the themes "disconnection" and "invisibility." In Atay's novel, the anti-hero Selim Işık says: "My life was a game, but I wanted it to be taken seriously" (Atay, 2018: 31) and the novel, the game, has begun with his suicide, and his friend Turgut's inner journey to follow the signs of Selim. Throughout the novel, he searches Selim's life and tries to understand what happens to him. He reads his letters, he meets his friends and associates himself with Selim who is the symbol of all alienated individuals whom are called "the disconnected." Like Selim, he is the disconnected man too, who experiences the traumas of alienation and loneliness. Just like Selim and Turgut, the nameless invisible man in Ellison's novel is also a disconnected man, whom cannot be seen by the others. The Invisible Man, the black American, is alienated by the dominant ideology of his culture and tells the reader that: "I am an invisible man...I am invisible, understand, simply because people refuse to see me" (Ellison, 2004: 7). He tries to survive in the inhospitable setting of New York. Ellison and Atay offer severe critiques of the dominant ideologies of different cultures and displays the ways through which the characters manage to survive in such a cruel world.

This study aims to propose a new reading of Atay's The Disconnected and Ralph Ellison's Invisible Man. The comparative analysis of the literary texts focuses on the construction of a literary bridge between American and Turkish culture in the twentieth century. The comparative reading offers a new way for the readers to analyze the literary works from a different perspective. Although Atay's work has been the subject of various academic studies, it has been rarely discussed comparatively with other authors either from his country or from other countries. His success as a turning point in Turkish novel, which was obviously ignored at the beginning of his career, created a kind of shield around him which has prevented his works to be discussed on a global basis. In the introduction part of the study, the aim and method of the study will be analyzed. The second part of the study will aim to shed light upon the term alienation within the frames of Hegel's concept of alienation to understand the alienated heroes of the novels and his master-slave dialectic to analyze the settings in which the characters overcome their alienated bodies and inner self's. In the third part, the alienation process of the characters will be discussed from the perspectives of thematic analysis and imagology focusing on the terms "the disconnection" and "invisibility" and the ways they overcome their alienation. Although the characters begin their stories as the slaves of the society, in the second part of their stories they win the battle against their masters and declare their independence. In order to highlight their success stories, both authors use common images in the novels. In relation, in the last part of the study, the commonalities and differences between the two novels will be discussed.

Keywords: Comparative Literature, The Disconnected, Invisible Man, Alienation, Master-Slave Dialectic, Oğuz Atay, Ralph Ellison.

Öz: Sosyal yaşamın bir parçası olan yabancılaşma kavramı, zaman, mekân, toplumsal farklılık gözetmeksizin evrensel bir tema hâlini alarak yazının da önemli durak noktalarından biri hâline gelmiştir. Oğuz Atay'ın Tutunamayanlar (1972) ve Ralph Ellison'un Görülmeyen Adam (1952) adlı eserleri de yabancılaşma kavramı üzerinde durarak evrensel yalnız bireyin serüvenini Türk ve Amerikan toplumu üzerinden yansıtmaktadır. Her iki eserde de ana karakterler yabancılaşma durumu ile karşılaşmaları ve bu durumun üstesinden gelebilmeleri için geliştirdikleri yöntemlerle ortak bir alan yaratırlar. Türk toplumunda yabancılaşmış bireye Atay "tutunamayanlar" motifi ile ışık tutarken, Ellison Amerikan toplumundaki yabancılaşmış bireye "görülmemek" motifi üzerinden seslenir. Atay’ın zihinsel sürgüne mahkûm edilen ve tutunamayan Turgut Özben ve Selim

Turkish Studies - Language, 15(3) 
Işı adlı karakterleri de tam da bu noktada bedensel sürgüne mahkûm edilen Görülmeyen Adam ile edebi olarak kesişir. Farklı coğrafyalardan okuyucuya seslenen karakterler, topluma ve özbenliklerine yabancılaşma hâllerinden, içinde bulundukları döngüden, kendilerine has geliştirmiş oldukları stratejiler yoluyla çıkmayı başarırlar. Karakterlerin pasif direnişlerini yansıtan; yeniden doğuş, kurtuluş ve sürgünün sona ermesi gibi imgeler ağı üzerinden incelenebilecek olan eserler yabancılaşan insanın hikayesini aktarmaktadır. Bu çalışmanın amacı farklı dillere ve kültürlere ait olan Tutunamayanlar ve Görülmeyen Adam eserlerindeki yabancılaşma izleğini, Hegel'in yabancılaşma ve Efendi-Köle diyalektiğine dayanarak, "tutunamamak" ve "görülmemek" motifleri üzerinden karşılaştırmalı edebiyat verileri 1şığında, çoğulcu yöntem doğrultusunda incelemektir. Çalışmanın sonunda karakterlerin yabancılaşma evreleri ve yabancılaşmış bedenleri ve ruhları aracılığg ile bu evrelerden kurtuluş süreçlerindeki benzerlikler ve farklılıklar değerlendirilecektir.

Anahtar Kelimeler: Karşılaştırmalı Edebiyat, Tutunamayanlar, Görülmeyen Adam, Yabancılaşma, EfendiKöle Diyalektiği, Oğuz Atay, Ralph Ellison.

\section{Giriş}

Diğerlerinin nasıl ayakta kaldığını bilmek, bizim de nasıl ayakta kalabileceğimizi bilmemize olanak sağlar ve nasıl ayakta kalacağımızı bilmek, hatalarımızı düzelterek kurtulmamızı mümkün kılar. Bizim sorunumuz budur. (Matthew Arnold 1857) ${ }^{1}$

Toplumsal yaşamın sosyolojik, psikolojik ve ekonomik başta olmak üzere pek çok farklı dinamikten oluştuğu bir dünya düzeninde birey yalnızca kendi toplumunda yaşanan değişim süreçlerinden değil farklı toplumların deneyimlerinden de faydalanarak gelişim sürecine devam etmektedir. Matthew Arnold, 1857 yılında Oxford Üniversitesi'nde yaptığı konuşmasında bu konuya dünya edebiyatı üzerinden vurgu yaparak gelişebilmek ve dönüşebilmek için bizim dışımızdakileri, ötekini, anlamının önemimin altını çizmektedir. Tam da bu noktada karşılaştırmalı edebiyat biliminin, kişinin bakış açısına dolayısıyla kendini ve diğerlerini algılama potansiyeline sağladığı katkı ortaya çıkmaktadır. Emel Kefeli'nin ifade ettiği gibi:

Karşılaştırmak bir bakıma kişinin “öteki” ile karşı karşıya gelmesi ve onu keşfetmesi demektir. Bunu yaparken kişinin önce kendisi ile sonra da "öteki”" ile sürekli bir iletişim halinde olması gerekir. Kişi ötekini tanımaya çalışırken kendisini de keşfeder. (Kefeli, 2000: 7)

Bu açıdan incelendiğinde “...ulusal filolojilere önemli katkılarda bulunma potansiyeline..." sahip olan karşılaştırmalı edebiyat bilimi (Cuma, 2019: 12) son yıllarda ülkemizde de çok önemli bir sanat dalı haline gelmiştir. Gürsel Aytaç'ın da ifade ettiği gibi "Kendi ülkesinden farklı olan yapıları araştırmak, kişide belli bir eleştiri ruhu geliştirir; kendinin olana, bu yapıları dikkatli bir biçimde inceledikten sonra başka bir gözle bakmayı öğretir"(2019: 18). Disiplinlerarası olması sebebiyle, karşılaştırmalı edebiyat bilimi, sahip olduğu çok katmanlı yapısıyla kültürlerarası bir köprü görevi kurarak yalnızca kendi toplumumuzu anlamada değil başka toplumları da anlama konusunda önemli bir misyon üstlenmektedir. Farklılıkları benimseyebilme ve hoş görmenin büyük bir ihtiyaç olduğu 21. Yüzyılda, karşılaştırmalı edebiyat bilimi araştırmacılara ve okuyuculara anlamlı bir katkı sağlamaktadır. ${ }^{2}$

Türk edebiyatında adeta bir milat olarak algılanan Tutunamayanlar romanı da, Atay'ın farklı kültürlere ait eserleri incelemesi ve irdelemesinin ulusal filolojiye ne denli önemli bir katk1

\footnotetext{
${ }^{1}$ Metin içerisinde yabancı kaynaklardan yapılan tüm çeviriler yazara aittir.

${ }^{2}$ Karşılaştırmalı edebiyat biliminin yazınlararasılık üzerinden detaylı bir değerlendirmesi için bkz. Cemal Sakallı (2006). Karşılaştırmalı Yazınbilim ve Yazınlararasılık / Sanatlararasılık Üzerine. Seçkin.
} 
sağladığının bir örneğidir. ${ }^{3}$ Atay, "tutunamamak" kavramı ile benzer duygu durumu yaşayan bireylere ayna tutmaktadır. Ralph Ellison da Görülmeyen Adam adlı eserinde "görülmemek" kavramını yalnızca siyahi Amerikalılar için kullanılan bir kavram olmanın ötesine taşıyarak tıpkı Atay gibi yalnızlaşan ve yabancılaşan insanın sembolü hâline dönüştürür. ${ }^{4}$ Atay'ın 1972 yılında yayımlanan romanı, Turgut Özben adlı genç bir mühendisin kaybolma haberinin okurla paylaşılması ile başlar. Hikâye, Turgut'un yazdığı belirtilen notların trende tanıştığı bir gazeteciye yayımlanması için gönderdiği 'Tutunamayanlar' metni 1şığında devam eder. Söz konusu notlar, Turgut'un Selim Işık adlı arkadaşının intihar haberini alması ve bu olayı araştırmaya başlaması ile ulaştı̆ı bilgiler üzerinden ilerler. Kendine ve topluma yabancılaşan ve bunun sonucunda da intihar eden Selim'in hikâyesi, Turgut'un aktarımı ile yalnızlaşan insanın bir yansıması hâline gelir. Dolayısıyla ötekileştirilen, tutunamayan Selim, tüm tutunamayanların sembolü olur. Ellison da 1952' de yayımlanan eserinde, yabancılaşan ve yalnızlaşan bireyin serüvenini bu kez Amerikan toplumu üzerinden anlatır. Atay, yabancılaşma kavramını ifade eden "tutunamamak" motifini kullanırken, Ellison "görülmemek" motifini kullanır. Afrika kökenli isimsiz bir erkeğin hikâyesini anlatan yazar, egemen beyaz kültür tarafından ötekileştirilerek yalnızlaşmak zorunda bırakılan yabancılaşmış insanı yansıtır. Amerika'nın yoksul bir köşesinden gelip, burs kazanarak eğitim şansı yakalaması ile başlayan hikâyesi, okuldan atılması, Harlem'e gitmesi, devrimci harekete katılması ve New York'ta evine, inine, çekilmesi ile son bulur.

Bu çalışmanın amacı, farklı kültürlerde farklı zaman dilimlerinde kaleme alınan Türk Edebiyatı'nın başyapıtları arasında gösterilen Oğuz Atay'ın Tutunamayanlar ve Amerikan Edebiyatı'nın başyapıtlarından Görülmeyen Adam adlı eserleri karşılaştırmalı edebiyat bilimi verileri 1şı̆̆ında incelemektir. Yabancılaşma izleğine 1şı tutan "tutunamamak" ve "görülmemek" motifleri izlekbilim ve Hegel'in yabancılaşma kavramı ve efendi-köle diyalektiği kullanılarak ele alınacağından çoğulcu (eklektik) inceleme yönteminden yararlanılacaktır. Gürsel Aytaç'a göre çoğulcu inceleme yöntemi “... araştırmacıya bir anlatım rahatlığı sağlayan, onu tek bir yöntem içinde bunalıp kalmaktan...” kurtarmaktadır (Aytaç, 2019: 101). İki eserin ana karakterlerinin yaşadığ1 yabancılaşmanın ve bu durumun üstesinden gelme yollarının ne denli benzerlikler ve farklılıklar gösterdikleri üzerinde durularak iki farklı kültürde yabancılaşan insanın izi sürülecektir.

Bu çalışmanın giriş kısmında çalışmanın amacı, yöntemi ve kapsamı açıklanmaktadır. İkinci bölümde, yabancılaşma kavramı ve efendi-köle diyalektiği incelenecektir. Üçüncü bölümde, romanların ana karakterlerinin deneyimledikleri yabancılaşma süreçleri, yabancılaşma kavramını yansıtan, "tutunamamak" ve "görülmemek" motifleri üzerinden izlekbilim verileri 1şığında incelenecektir. Benzerlikler ve farkl1lıklar üzerinde durulacak ve farklı toplumlarda tutunamayan ve görülmeyen bireyin sosyolojik yansıması irdelenecektir. Dördüncü bölümde, başkişilerin yabancılaşma hâllerini, tersine çevirmeleri ve egemen toplum yapısına karşı olan savaşlarında galip gelmeleri üzerinde durulacaktır. Hegel'in yabancılaşma ve efendi-köle diyalektiği üzerinden incelenecek olan bu bölümde benzerlikler ve farklılıklar ortaya konmaya çalış1lacak ve ortak motif ve imgeler izlekbilim ve imgebilim verileri ışığında incelenecektir. Beşinci bölüm olan sonuç

\footnotetext{
${ }^{3}$ Metin içi metin yaratımıyla, Türk Edebiyatı'nın ilk bilinçli üstkurmaca örneği olan Tutunamayanlar romanı, Atay’ın, Camus, Hegel, ve Fichte gibi pek çok düşünüre ait eserleri okumuş olmasının yarattı̆̆ bilgi birikimi ve farklı kültürlere dair sahip olduğu donanımı başarıyla yansıtmaktadır. Her ne kadar bazı eleştirmenler romanın başarısını farklı eserlerden etkilenmeye dayandırsa da bu durum metinlerarasılık göz önünde bulundurulduğunda olumlu bir hal almakta ve çürütülmektedir. Jale Parla, bu eleştirel tutumu, laneti, Atay’ın ilk iki kitabı ile deneyimlediğini ve eleştirileri, eserlerinin avangardlığına dudak büken bir kesim entelektüelin tavrı olarak tanımlar (2015: 131). Metinlerarasılık ile ilgili detaylı okuma için bkz. Kubilay Aktulum (1999). Metinlerarası İlişkiler. Öteki Yayınları ve (2011) Metinlerarasılık/Göstergelerarasılık. Kanguru Yayınları. Tutunamayanlar romanına dair eleştiriler ile ilgili bkz. Jale Parla (2015). Türk Romanında Yazar ve Başkalaşım. İletişim.

${ }^{4}$ İki eseri birbirine bağlayan bir diğer unsur ise her ikisinin de modernist ve postmodernist romanın özelliklerini taşımasıdır. Modernist romanın depresif ve umutsuz tonunun yanı sıra postmodern edebiyatın önemli bir öğesi olan sanatı bir tür oyun olarak görme hâli her iki eserde de rastlanan bir durumdur. Özellikle Tutunamayanlar'da bu duruma atıfta bulunularak 'oyun' kelimesi sıklıkla kullanılır.
} 
kısmında ise belirlenen yöntemler doğrultusunda roman karakterlerinin farklı toplumlarda deneyimledikleri yabancılaşma süreçleri, bu süreçleri tersine çevirme yöntemleri, izledikleri yollar arasındaki benzerlikler ve farklılıklar değerlendirilecektir.

\section{Yaşayan Bireyin Anatomisi: Yabancılaşma}

...tiranlık, bedeni özgür bırakır ve saldırısını dosdoğru ruha yöneltir. Hükümdar artık şöyle demez: Ya benim gibi düşün ya da öl. Şöyle der: Benim gibi düşünmemekte özgürsün; yaşamın, malın, mülkün, her şeyin senin olarak kalacak, ama bugünden itibaren aramızda bir yabancisın.

Alexis de Tocqueville. (akt. Adorno ve Horkheimer 2010: 178).

Eski Yunanca'da "alloiosis" kelimesinden türetilen Latince "alienatio" kökenli olan yabancılaşma (alienation) kavramı tarih boyunca sosyal yaşamın bir parçası olmuştur. "Çağdaş psikolojide ya da sosyolojide, kişinin kendisine, içinde yaşadığı topluma, doğaya ve başka insanlara karşı duyduğu yabancılık hissi"(Cevizci, 2000: 994) olarak tanımlanabilecek olan yabancılaşma, yalnızca psikolojik ve sosyolojik değil felsefi boyutları da olan bir kavramdır. Melvin Seeman, yabancılaşma hâlini bireyin özünden ve geçmişinden bağlantısal olarak koparak geçirdiği; güçsüzlük, anlamsızlık, kuralsızlık, yalıtılmışlı (tecrit olgusu) ve kendine yabancılaşma gibi boyutlardan oluşan bir süreç olarak tanımlamaktadır. (Seeman, 1959: 784-89) Yabancılaşma hali kimileri için "insan doğasının parça parça" edilmesi olarak da okunabilmektedir. (Ollman, 2015: 220). Toplumun bir yansıması olan edebiyat da bu kavrama kayıtsız kalmamış, 20. yüzyılın en önemli gerçekliklerinden biri olan yabancılaşma kavramını pek çok eserin ana lokomotifi haline getirmiștir. Albert Camus'un Yabancı (1942) romanı buna en önemli örneklerden biridir. Türk Edebiyatı'nda özellikle 1950'lerden sonra ivme kazanan yabancılaşma kavramı Yusuf Atılgan'ın kaleme aldığ 1 Aylak Adam (1959), Melih Cevdet Anday'ın Aylaklar (1965) ve Latife Tekin'in Sevgili Arsız Ölüm'ü (1893) ve Bilge Karasu'nun Gece (1985) adlı eserlerinde öne çıkmaktadır. Amerikan Edebiyatı'nda da 20. Yüzyıl yabancılaşma kavramının ele alınışı bakımından son derece verimli bir dönemdir. William Faulkner'ın Döşeğimde Ölürken (1930) Ernest Hemingway'in Güneş de Doğar (1926) ve Willa Cather'ın Profesörler Evi (1925) yabancılaşma kavramı ile öne çıan eserlerdir. Türk edebiyatının ilk postmodernist romanı olan Tutunamayanlar ise alışılagelmiş tekniklerin dışına çıkarak yabancılaşan insanı resmetmiştir ve Tutunamayanlar başlığı toplumda benzer duygu durumunu yaşayanlar kişiler arasında oldukça popüler bir kavram halini almıştır. Görülmeyen Adam'da ulusal sınırları aşarak yalnızca siyahi Amerikalılar'ın değil kendini bu yaşamda anlaşılmamış ve göz ardı edilmiş hisseden herkesin ortak alanı olmuştur. Ephraim Mizruchi'nin de belirttiği gibi "yabancılaşma, uzun zamandan beri 19. ve 20. yüzyıl yazarlarının eserlerinde egemen bir kavramdır" (Mizruchi, 1973: 111) ve Atay ile Ellison'un eserleri de buna anlamlı birer örnektir.

Tarihsel olarak incelendiğinde, yabancılaşma kavramı pek çok düşünür tarafından ele alınmış ve genel olarak Karl Marx ve Rousseau gibi iktisadi ve siyasi bir çerçeve üzerinden yorumlanmıştır. Georg Wilhelm Hegel ise sosyolojik, psikolojik ve felsefi boyutları olan bu kavramı, var olan sınırların dışına çıkararak oldukça geniş bir perspektiften ele almış ve bu kavrama olumlu bir anlam yüklemiştir. Eserleri incelendiğinde, yabancılaşma kavramına karşılık gelen "Entfremdung" (Inwood, 1992: 35) ve dışsallaşma anlamına gelen"Entausserung" (Inwood, 1992: 36) kavramları göze çarpmaktadır. İlk kez Hegel tarafindan belirli bir çerçevede ele alınan yabancılaşma kavramı, kişinin kendi bilincine varma serüveni olarak yorumlanmıştır. Hegel'e göre kişinin içinde bulunduğu doğaya yabancılaşma süreci doğal bir süreçtir ve kişi ruhsal gelişimini tamamlamasıyla birlikte yabancılaşmış benliğinin üstesinden gelerek bu süreçten çıkacaktır. Yabancılaşma, “"Mutlak Ruh"un kendini dışsallaştırması için zorunludur ve "Mutlak Ruh"un

${ }^{5}$ Yabancılaşma, Farsça kökenli yaban sözünden türetilmektedir. Farsça'da boş ve ıssız yer anlamına gelen 'yaban'dır.' Detaylı bilgi için bkz. İsmet Zeki Eyüboğlu (1995). Türk Dilinin Etimolojik Sözlüğü. Sosyal Yayınlar, 3. Basım. s. 714. 
kendine dönme sürecinde aşılarak üstesinden gelinecektir"'(Sayers, 2003: 120). Yabancılaşma, Hegel felsefesinde "Mutlak Ruh'un" yabancılaşma ve yabancılaşmanın dışına çıkma süreci ile tanımlanan pasif olmayan, görünenin aksine dinamik bir benliktir. Birey kendi ruhunun farkına vararak gelişir ve yabancılaşma sürecinin içinden çıkmayı başarır. Bir başka ifadeyle, toplumun bir parçası olan bireyin yabancılaşma süreci her ne kadar bir kopuş, bir ayrışma ile başlasa da bu kopuş bir birleşme, tamamlanma ile sonlanacaktır. (Schacht, 1989: 39).

Hegel 'in "Mutlak Ruh'un" deneyimlediği doğal bir süreç olarak tanımladığı yabancılaşma, ruhun kendini tamamlaması ile son bulan ve bu özgürleşmeye varabilmek için zorunlu olan doğası gereği aş1labilecek bir durumdur (Sayers, 2003: 120). Hegel'in yabancılaşmaya, dışsallaşmaya, yüklediği olumlu anlam tarih anlayışında saklıdır. Hegel'e göre: "Dünya Tarihi bir mutluluk sahnesi değildir. Ondaki mutluluk dönemleri boş sayfalardır, çünkü bunlar karşıtlığın askıya alındığı uyum dönemleridir "(2006: 27). Bu yüzdendir ki Hegel, tarihsel süreçte ortaya çıkan sorunları veya mutsuzlukları bir olumsuzluk çatısı altında nitelendirmez. Yaşanan olumsuzluklar, Tin'in yabancılaşmasının doğal bir parçasıdır ve değişim için gereklidir. Karşıtlıkların ve sorunların varlığı, Tin'in kendini tanıma sürecine katkı sağlayarak tarihsel mutsuzlukları kaynak olarak kullanır. Bu yolla gelişmeye ve ilerlemeye devam eder. Özgürlüğe ulaşması da özünü bu ilerlemeden almaktadır.

Hegel'e göre insan özgürdür ve bu özgürlük yabancılaşmanın da bir parçasıdır. İnsan, özgür iradesi doğrultusunda bu yabancılaşma halinin de üstesinden gelebilmektedir. Hegel'e göre "Doğada aklın eseri zorunluluğa zincirlidir. Ama Tin'in ülkesi özgürlüğün ülkesidir. İnsan yaşamının bağını meydana getiren ne varsa, insan için değer taşıyan ne varsa hepsi tinsel, tabiattadır..."(Hegel, 1976: 11) ve bu yüzden de değişime doğası gereği açıktır. Hegel'in efendi-köle diyalektiğinin bir parçası olan köle, doğası gereği içinde barındırdığı özgürleşme gücü ile insanın yabancılaşması ve bu yabancılaşmanın üstesinden gelme sürecine benzer bir deneyime ev sahipliği yapmaktadır. Georg Wilhelm Friedrich Hegel'e göre tarih; iki isteğin ve iki insan tipinin karşı karşıya geldiği efendi ile köle arasındaki diyalektiğin üzerine kuruludur:

\begin{abstract}
Eğer insansal varlık, kendini ancak, Efendi ile Köle arasındaki ilişkiye ulaşan mücadelede ve mücadeleyle ortaya çıkarabiliyorsa, bu insansal varlığın adım adım ilerleyen gerçekleşmesi ve açığa-vuruluşu da ancak, bu temel toplumsal ilişkiye bağlı olarak gerçekleşebilir. Eğer insan, kendi değişip-oluşmasından başka bir şey değilse; eğer insanın mekândaki insansal varlığı, zamandaki varlığıysa ya da zaman olarak varlığıysa, eğer açığa-vurulmuş insansal gerçeklik, tümel (evrensel) tarihten başka bir şey değilse, bu tarihin, Efendilik ile Köleliğin arasındaki etkileşimin tarihi olması gerekir; dolayısıyla, tarihsel "diyalektik", Efendinin ve Kölenin "diyalektiğidir." (Kojeve, 2001: 85)
\end{abstract}

Güçlerin eşit olmadığı her ilişki de insan ya bir köle ya da bir efendidir. Bu diyalektikte, insan kendi bilincine ulaşma ve bu bilinci başkaları için kabul edilebilir kılmaya çalıştığı bir nesnelleşme sürecini deneyimler. Efendi ile köle arasındaki tarihsel mücadelenin kaynağını bu tanınmayı istemek oluşturur çünkü bu savaş "bilinip-tanınmaya" yönelik katıksız bir prestij mücadelesidir" "(Kojeve, 2001: 89). Hegel'e göre bu bilinip tanınma isteği yeterli değildir aynı zamanda bir gözü peklik de gerektirmektedir. Ölümüne mücadele ederek, bu gözü pekliğe cüret edecek olan taraf efendi konumuna geçebilecektir. Korkularına yenik düşen ise köle olacaktır. Efendi, buna cüret ederek kendini kabul ettirme amacına ulaşarak bilinir ve tanınır olmayı başarır, bu durum köleye efendiyi bir güç olarak tanımak ve onun önünde eğilmekten başka bir yol bırakmaz. Hayatına devam edebilmek için köle, efendiyi tanır ve hasmına boyun eğer. "Yani, kendi isteğini bir yana bırakmak ve ötekinin isteğini doyuma ulaştırmak zorundadır; ötekini (hasmını), onun tarafından "biliniptanımaksızın" "bilip-tanımak", onu efendi olarak "bilip-tanımak" ve kendini Efendinin Kölesi olarak bilip-tanımak ve tanıtmak zorundadır" (Kojeve, 2001: 85). Hikayesinin başında kabul eden, tanıyan, taraf olan köle, özünde değişime adaydır çünkü bir parçası olduğu diyalektik doğası gereği kendi bilincine vararak bu bilinci nesnel hale getirme ve sonuç olarak da özgürleşmeye olanak tanımaktadır. Tülin Bumin'in ifade ettiği gibi: 
İnsan başlangıçta ya köle ya da efendi olduğuna ve efendinin karşılıklı kabul edilme amacına, dolayısıyla da gerçek bir doyuma ulaşması mümkün olmadığına göre, bu amaca ve onun vereceği doyuma ulaşacak olan köle olacak, "daha doğrusu, köle olmuş olan, kölelikten geçmiş olan, köleliğini ‘diyalektik olarak' ortadan kaldırmış olan” olacaktır. Başka bir deyişle, diğer bir özbilinç tarafindan kabul edilmiş özbilinç hâline gelmeye aday olan efendi değil köledir. (Bumin, 2019: 40)

Efendi, “...kendi Efendiliği içinde donmuştur. Kendisini aşamaz, değişemez, ilerleyemez” (Kojeve, 2001:100) oysa köle için bu durum söz konusu değildir. Efendi her ne kadar kölenin kendini tanıtma isteğine kayıtsız kalsa da, kendisine bırakılan alanda köleye, doğayı dönüştürme ve bu çalışmasını ileriye taşıyabilme özgürlüğü verir. Köle bu diyalektikte avantajlı olan taraftır çünkü;

Kölede, sabit ve yerine oturmuş hiçbir şey yoktur. Değişmeye hazırdır o; varlığının ta kendisinde değişimdir, aşmadır, dönüşüme-uğramadır, "eğitimdir"; kökeninde, özünde,varlığının kendisinde bile, tarihsel değişip-oluşmadır. Bir yandan, ne ise o olmaklığıyla dayanışma içinde değildir; verilmiş durumunu olumsuzlayarak kendini aşmak istemektedir. Öte yandan, ulaşmak istediği bir pozitif ideali vardır onun ve bu, köleliğinin ta kökeninde, Efendide ete kemiğe bürünmüş olarak bulduğu özerklik ve Kendi için varlık idealidir. (Kojeve, 2001: 100)

Doğası gereği özünde bulundurduğu değişim kapasitesi sayesinde köle, hasmını (antiteyi) tamamen bir ortadan kaldırma, bir olumsuzlama, mücadelesi içine girmez, nihai sona ulaşmayı arzulamaz. Efendiyi kısmen muhafaza eder ve onu hükümsüz kılan değil ileriye taşıyan diyelektik bir olumsuzlamayı (aufhebung) destekler. Bu süreçte köle için hasmını tamamıyla ortadan kaldırmak işlevsel değildir bu yüzden de "diyalektik" olarak hasmını ortadan kaldırmaya ve sahip olduğu özerkliği baltalamaya gereksinim duymaz. Köle, özgürlüğünü efendiyi ortadan kaldırmaya çalışarak değil aradaki ilişkiyi olumsuzlayarak ve efendinin kendi üzerindeki kurduğu gücü ortadan kaldırarak ilan eder. Böylelikle köle, kendini bilip tanıyarak üzerinde var olan efendi düşüncesini yıkar.

Tutunamayanlar ve Görülmeyen Adam eserlerinde, hikayelerine birer sembolik köle olarak başlayan ana karakterler, yabancılaşma süreçleri sonunda özgürleşmeye de adaydırlar. Hegel'e göre kendine yabancılaşmış bir tin olan insan, doğası gereği yabancılaşma ve bu yabancılaşma sürecinden özgürleşme halini deneyimleyecektir. Atay ve Ellison'ın eserlerinde yabancılaşma izleği, teması, psiko-sosyal sonuçları ve yansımaları açısından "tutunamamak" ve "görülmemek" motifleri üzerinden açılanabilmektedir. ${ }^{6}$ Bu bağlamda incelendiğinde, "tutunamamak" ve “"'görülmemek motifleri baş karakterlerin toplumsal yapı içerisindeki yabancılaşma süreçlerine 1şık tutmaktadır. ${ }^{7}$ Dışlanma, yalnızlaşma, sembolik sürgüne gönderilme hâli yabancılaşma izleğinin tanımlanmasında bedenin ve ruhun toplumsal yapı içerisinde tutunamaması, düşerek parçalanması ve görülmemesi olarak ortaya çıkmaktadır. ${ }^{8}$ Sonuç olarak farklı toplumlarda var olma mücadelesi veren

\footnotetext{
6“'̇zlekbilim, metin içinde kullanılan izlek, imge, motif ve simge gibi anlatıbilim öğelerinin araştırılmasını, sınıflandırılması, kullanım biçimleri ve kökenlerini araştıran ve bunlara ilişkin sonuçları ortaya koyan yöntem biliminin adıdır. İzlek ya da tema diye adlandırılan kavramların ve bu kavramların diğger benzer biçim ve görünümlerini araştırmayı, hangi yolla, hangi bağlamda ve hangi biçimde kültürlerarası geçişlere sahip olduklarını araştırmayı hedefler....̇̇zlek, bir metinde yer alan, metnin içeriğini, neyin üzerine yazıldığını veya kısaca konusunu ifade eden, çoğunlukla da soyut nitelikli olan kavram ya da k1sa ifadedir." (Atalay, 2019: 87)

7 “...motif, belli basit durumlarda veya olaylarda, yaşantılarda görülebilen genel insani sorunlardır” (Kefeli, 2000: 174) ve "[m]otif, izleği ortaya koymakta alegorik bir anlama sahip olan somut bir öğedir." (Atalay ,2019: 100)

8 Sosyolog W.E.B. Du Bois bu durumu 1903 yılında Siyah Halkın Ruhu adlı çalışmasında kullanmış olduğu "çift bilinçlilik" (double conscioussness) kavramı ile açıklayarak literatüre dâhil eder. Amerika'da var olma mücadelesi veren Afrikalı-Amerikalılar için kullanılan kavram, kendilerini sürekli olarak egemen toplum yapısının gözünden görmek zorunda kalma ve bunun sonucunda yaşanan kimlik bölünmesi ve bir olamama hâlini ifade etmektedir. (Du Bois, 1994: 2)
} 
kahramanların hikâyeleri yabancılaşan, görülmeyen ve tutunamayan bireyin özgürleşme yolculuklarına 1şık tutmaktadır. ${ }^{9}$

\section{Yabancılaşma Kavramının Ayna Benliği: “Tutunamamak” ve “Görülmemek” Motifleri}

Tutunamayanlar, Selim Işık'ın dolayısıyla Turgut Özben'in egemen toplumsal yapıya ve kendine yabancılaşmış tutunamayan insanın tanımlanması ile okuyucuyla buluşur. Söz konusu tanım, "bu toplumla ilişkisini kaybetmiş: yaptığı işe ve yaşadığı düzene yabancılaşmış" (Atay, 2018: 99) “...günümüzün insanlarına uymadığı kolayca”(Atay, 2018: 21) fark edilebilecek Selim Işsk ve onun yansıması olan yabancılaşmış insanı portrelemek için kullanılır. Dolayısıyla yabancılaşmış bireyin her iki eserdeki tanımlanma yolu farklı olsa da ortaya çıkan anlam ortaktır. Tutunamayanlar'da Garip Yaratıklar Ansiklopedisi'nden okuyucunun edindiği bilgiye göre:

Tutunamayan (disconnectus erectus): Beceriksiz ve korkak bir hayvandır. İnsan boyunda olanları bile vardır. İlk bakışta, dış görünüşü ile insana benzer. Yalnız, pençeleri ve özellikle tırnakları çok zayıftır. Dik arazide, yokuş yukarı hiç tutunamaz. Yokuş aşağı, kayarak iner. (Bu arada sık sık düşer.) Gözleri çok büyük olmakla birlikte, görme duygusu zayıftır. Bu nedenle tehlikeyi uzaktan göremez. (Atay, 2018: 149)

Selim Işık, bedeni ve zihni özgürlükten yoksun bırakılmış, egemen toplum yapısı tarafından ötekileştirilerek yaptığı işe ve sonuç olarak da topluma yabancılaşan bir insan hâline dönüşmüştür. $\mathrm{Bu}$ durum onu, yabancılaşmanın idolü olarak gören Turgut Özben ve tüm tutunamayanlar için birleştirici bir alan hâline getirir ve "Tutunamamak", bir motif olarak yabanc1laşma izleğini ortaya koymak için kullanılır. Görülmeyen Adam ise Selim Işı1k ve Turgut Özben'in aksine isimsizdir. Bu kimliksizlik vurgusu, Amerikan toplumunda kölelik deneyimlemiş olan ve tarih boyunca yabancılaşan insanın, siyahi Amerikalıların, tanımlanma şeklidir fakat karakter "Ama kim bilir, düşük frekanslarda, sizin adınıza konuşuyorumdur belki de?" (Ellison, 2004: 544) diyerek yabancılaşan tüm bireylerin ortak sesi olduğunu çok net bir biçimde ifade eder. ${ }^{10}$ Yabancılaşma, modern Amerikan romanının ayrılmaz bir temasıdır (Klein 1964, Putz 1979) ve Görülmeyen Adam'ın hikâyesi ile beden bulmaktadır.

İki grubun çatışmasının doğal bir sonucu olarak ortaya çıkan yabancılaşma, Görülmeyen Adam tarafından da tutunamayanlar gibi benzer bir biçimde açılanır: "Vardım ama yine de görülmezdim temel çelişki buydu. Vardım ama yine de görülmüyordum”(Ellison, 2004: 474). Kahraman, okuldan talihsizlikler sonucu atılması ile kendini egemen beyaz ırkın ona uygun gördüğü yerde yani bir fabrikada bulur ve "bir işçi dalgası içine düş_er]' (Ellison, 2004: 186). İroni yaparak boya fabrikasının "HÜRRIYET BOYALARIYLA AMERIKA'YI TEMIZZ TUTUN" (Ellison, 2004: 186) reklam sloganını adeta boya ile kapatılmaya çalışılan eşitsizlik vurgusu üzerinden okur. Tıpkı, işçinin görmezlikten gelinen arzu ve istekleri gibi Görülmeyen Adam ve Tutunamayanların da egemen toplumsal yapı içerisinde tüm özgürlük alanları yok sayılır ve görmezden gelinir. Amerikan toplumunda işçi sınıfında, bir siyahi olarak, ikinci sınıf vatandaş muamelesi gören Görülmeyen Adam'ın aksine, Türk toplumunda Turgut Özben ve Selim Işık zihinsel farklılıkları ve farkındalıkları sebebi ile dışlanmayı deneyimlerler. Selim ve Turgut, toplumun egemen sınıfına ters düşen, kendi

\footnotetext{
${ }^{10}$ H. G. Wells The Invisible Man (1897) Görünmez Adam adlı romanında 'the' kullanarak her ne kadar ana karakterine isim vermese de bu kişinin belirli bir kişi olduğuna vurgu yapar. Ellison ise, evrensel yabancılaşmış bireyi vurgulamak için bu spesifikleştirmeden kaçınır. Bunda, yabancılaşma ve ırkçılığı şiddetle yaşayan Amerikan tarihinin hiç şüphesiz etkisi büyüktür. Jim Crow yasaları olarak adlandırılan uygulamalar 1875'de Tenneessee'de kabul edilir. Bu sürecin başlamasıyla birlikte tüm Güney eyaletlerinde uygulamaya konularak, toplu taşımadan, kütüphaneye, okullardan, asansörlere kadar beyazların ve siyahların kullanabilecekleri alanlara asılan "Sadece beyazlara" gibi tabelalar ile resmileştirilir. Irkçılığın çok sert bir biçimde yaşandığı Amerikan toplumsal yapısının detaylı okuması için bkz. Edward. E. Baptist (2016). The Half Has Never Been Told. Slavery and Making of American Capitalism. Basic Books ve Peter Kolchin (2003) American Slavery. 1619 - 1877. Hill and Wang.
}

Turkish Studies - Language, 15(3) 
bildikleri yolda yürümeyi seçen aydın bireylerdir. Burjuva değerlerine başkaldırılar, okumaya, düşünmeye ve sorgulamaya vakit ayırırlar bu nedenle de içinde yaşadıkları toplum ile uyumsuzluk içindedirler. Selim 'mağara' olarak tanımladığı odasında okuyarak zaman geçirir ve kendini toplumdan ayrışmış hisseder. Tüm tutunamayanların temsilcisi olan Selim Işık için:

Onu görüyorlardı. Hiçbir şey yapmadan, aptalca bir düzen içinde yaşarken kimse görmüyordu. Sonra, alışılmışın dışında en küçük bir davranışını görüyorlardı. Nasıl görüyorlardı acaba? Sizi gördük, diyorlardı. Bütün gün sadece bakıyorlardı; sonra akşam evlerine dönünce rahat koltuklarına gömülüp kimleri gördüklerinin bir muhasebesini yapiyorlard1. (Atay, 2018: 555)

ifadesi kullanılır ve topluma aykırı bir duruş sergileyen Selim görünmez hale getirilir.

"Tutunamamak" ve "görülmemek" motifleri karakterlerin bedenleri aracıllı̆ı ile somut bir forma bürünür. ${ }^{11}$ İsimsiz kahramanın ve tüm tutunamayanların bedenleri tükenmiştir. Selim intihar etmiş, bedeni yok edilmiştir, Görülmeyen Adam, tüm tutunamayanlar gibi “...terk edilmiş yuva[sında]" (Atay, 2018: 149) inine, odasına, çekilerek yok olmuştur, Turgut kayıptır ve arkasında notları ile sırra kadem basmıştır. Karakterlerin deneyimledikleri yabancılaşma hâli bir nevi sürgün hâlidir. ${ }^{12}$ Turgut ve Selim sembolik olarak zihinsel bir sürgün yaşarlar. Misafirlerin yanına çıkmadığı ve çok kitap okuduğu için egemen toplumsal yapı Selim'e "anormal” teşhisi koymayı uygun görür. $\mathrm{Bu}$ durum Selim'i yabancılaşmanın doğal bir sonucu olan yalnızlaşmaya iter. "Bir sen miydin bu dünyada garip olan, Selim?" (Atay, 2018: 298) sorusuyla Turgut kendi deneyimlediği benzer yabancılaşmaya vurgu yapar. Turgut, Selim için "Selim Iş̧k yalnızlığa dayanamazdı. "İlk bakışta, yalnızlığın ve çevreyle uyuşmazlığın, yaşantısında önemli bir yer tuttuğu kolayca ileri sürülebilirdi" (Atay, 2018: 135) ifadesiyle tutunamamak hâlinin bir parçası olan yalnızlığa vurgu yapar. Bu zihinsel sürgün hâli o denli ağırdır ki Turgut: "Sebep olanların gözü kör olsun! Bir zamanlar tutunamayanlar diye bir söz etmiştim. Şimdi bu sözü çok hafif buluyorum" (Atay, 2018: 610) sözleriyle tutunamamanın ağırlığını irdelemektedir.

Selim ve tüm tutunamayanların Türk toplumunda deneyimlediği zihinsel sürgün, Görülmeyen Adam'ın hikayesinde beyaz sınıf tarafindan ötekileştirilen bedensel sürgün olarak ortaya çıkar. Bu toplumsal yapıdaki çatışma zihinlerüstüdür ve beden üzerinden gerçekleşir. Görülmeyen Adam “uzaklaştırılma belki de en iyisiydi”" (Ellison, 2004: 170) sözleriyle, burslu olarak okuduğu okuldan haksız yere atılarak New York'a zorla gönderilme durumunu yani sembolik bedensel sürgününü tanımlar. Bu acımasız bedensel sürgün edilme hâlini:

Görülmezim, anlıyor musunuz, sırf insanlar beni görmek istemedikleri için görülmezim.

Tıpkı sirklerde gördüğünüz bedensiz başlar gibi, sert, çarpıtıcı camdan yapılmış aynalar çevirmiş sanki etrafimı...en küçük şeyi görürler de beni görmezler. (Ellison, 2004: 7)

sözleriyle ifade eden anlatıcı, görülmezliğin ruhsal ağırlığına vurgu yapar. "Görülmeyen bir adamım ben. Yo, Edgar Allan Poe'nun peşini bırakmamış olan o hayaletlerden biri değilim; ne de o sizin Hollywood filmlerindeki dış plazmalardan biri" (Ellison, 2004: 7) derken de aslında "görülmemek"

\footnotetext{
${ }^{11}$ Görülmemek motifinin karşılaştırmalı olarak incelenmesine bir örnek olarak bkz. Devrim Ç. Güven (2020). Foucauldian "Medical Gaze" as an Ideological Apparatus of Modern Power Structures in the Works of Rifat Ilgaz, Ōoka Shōhei, JeanPaul Sartre and Joseph Conrad. Folklor/Edebiyat, 26 (101), 157-171. DOI: 10.22559/folklor.1148

${ }^{12}$ Feridun Andaç’a göre: “Sürgünlük, kaçınılmaz olanı yaşamaktır. Yersizliğin, yurtsuzluğun kıyısına gelinmekle başlar. Bunun ivmesi de koşulların gücünden gelir. Karşı konulan, savaşılan koşullarda yenik düşme sonrasında kaçınılıp sığınılacak bir yer/yurt arayışıdır tüm bunlar sonrasında yaşanılan. Kopuş burada başlar işte: bir yol çatına gelen üç kardeşler masal kahramanlarının dönüşsüz seçenekleri sunulmuştur ona; ya zorunlu olunanın kanatlarına takılıp gidecek, ya gönüllü bir yolun yolcusu olacak, ya da iç sızılarını yaşayacağı yolun kılavuzu kesilecek. Nereye, ne yöne de gitse kalbinde o sözlerin mührü olacak hep: SÜRGÜN.” (1996: 11) Andaç, önemli yazarların sürgün deneyimlerini şu sözlerle ifade eder: Örneğin "Thomas Mann, Stefan Zweig, Rafael Alberti, Pablo Neruda, Yannis Ritsos, Nâzım hikmet, Julio Cortazar zorunluydu; Henry James, Ernest Hemingway, Henry Miller, F. Scott Fitzgerald gönüllü; Marcel Proust, R.M. Rilke, Franz Kafka, James Joyce ise içsürgünlüklerini yaşarlar.” (Andaç: 1996: 13)
} 
motifini belirli bir tanıma indirgemek yerine evrenselleştirerek, yabancılaşan her bireyin ortak esaret alanına dönüştürür. Bu durumu "düşmanlık" (Ellison, 2004: 211) olarak tanımlayarak bedensel sürgününün ne denli ağır olduğuna vurgu yapar. ${ }^{13}$ Görülmeyen Adam bedensel olarak yok sayılır ve toplumun bir parçası olmak için tutunacak bir alanı hikâyesinin başında bulamaz. Turgut da Selim'in intiharı ile kendi yabancılaşması ile yüzyüze gelerek ne yapacağını bilemeden bir boşluk içerisinde tutunamadan yaşayıp gitmektedir. Karakterler, egemen yapı tarafindan görülmezler ve görülmemek onların sosyo-psikoljik alanlarının anahtar kelimesi hâline gelir. Oysa yaşadıkları yabancılaşma egemen yapının onları ötekileştirmeye çalışmasının farkına varma halidir ve karakterlerde bir nevi travma yaratarak yabancılaşmaya yol açacaktır. İsimsiz kahraman, Turgut ve Selim farkındalık hâllerini baş ağrısı ve beyin ile tanımlar. Baş ağrısı da bir motif olarak yabancılaşma izleğini tanımlamada kullanılır. ${ }^{14} \mathrm{Bu}$ bağlamda incelendiğinde, Turgut, Selim'in hikâyesinin peşinde koşarken sıklıkla baş ağrısı ve beyin rahatsızlıklarından bahseder:

...baş tarafim acı geliyor. (Atay, 2018: 719)

Dediğine göre, geçen gün kaldırımda yattığını gördüğümüz adam sar’alı değilmiş: Hazreti İsa imiş. (Atay, 2018: 719)

Hegel'in şiddetli baş ağrılarının "Başına gelenlerin hep felsefe ile uğraşmak yüzünden olduğu kuşkusuna kapıldı bir gün.” (Atay, 2018: 181)

Hegel: "18 Mayıs 1844 Perşembe günü akşamüzeri saat dört buçukta beyin kanamasından öldü.”(Atay, 2018: 182)

Farkındalık, karakterleri hasta eden bir yapı hâline dönüşür. ${ }^{15}$ Farkındalık; "Genelde bir şeyin bilincinde veya farkında olmak diye anlamlandırılır. Bu da salt bilinçten veya bilgiden daha fazlasını ifade eder; çok aşikâr olmayan, hatta beklenmedik bir şeyin keşfi anlamına gelir" (Fromm, 2017: 65). Kişinin gelişimine katkı sağlayan ve kendine yaklaşmasına olanak tanıyan farkındalık, bireyin bilinçlenmesi adına son derece önemli bir katkı sağlamaktadır. Osho "Ne kadar bilinçsizsen, o kadar kendinden uzaktasındır. Ne kadar bilinçliysen, kendine o kadar çok yaklaşırsın" (2004: 74) der. Bu bağlamda incelendiğinde, karakterleri onları hasta eden bir yapı haline getiren farkındalıklarının özlerine yaklaşma konusunda onlara katkı sağlayacağı aşikârdır. Turgut'un da belirttiği gibi "Meşhur adamların hayat hikâyelerinde, onların daha küçük yaştan öteki çocuklardan uzaklaştığını yazar çoğu zaman. Çocuk yaşta sezilen bazı kabiliyetleri, onları yalnızlığa sürükler” (Atay, 2018: 635-6).

Görülmeyen Adam da, tıpkı tutunamayanlar gibi, yabancılaşma sonucu ortaya çıkan yalnızlık duygusunu 'baş ağrısı' üzerinden betimler. Bedensel olarak yabancılaştırılan ve dışlanan siyahi bireyler "Başım dönüyor" (Ellison, 2004: 15) "Beni yalnız bırak, oğul, başım ağrıyor"

\footnotetext{
${ }^{13}$ Richard Wilkonson ve Kate Pickett Ruh Seviyesi adlı çalışmalarında, toplumsal eşitsizliğin sosyal yaşam üzerinde ne denli etkili olduğunu ve toplumdaki her şeyi etkilediğini ifade eder. Toplumsal eşitsizliğin ve ayrımcıllı̆ın birey üzerindeki etkileri için bkz. Richard Wilkinson ve Kate Pickett (2011). The Spirit level. Why Greater Equality Makes Society Stronger. Bloomsbury.

14 "İzlekbilimin en küçük yapı taşına motif denir” (akt. Atalay, 2019: 285) ve "Motif, izleği ortaya koymakta alegorik bir anlama sahip olan somut bir öğedir" (Atalay, 2019: 100). Baş ağrısı somut bir öğe olmamasına karşın, karakterlerin bedenini yansitarak sembolik anlamda somut bir forma bürünebilir ve bir motif olarak değerlendirilebilir.

${ }^{15}$ Yıldız Ecevit, Atay'ın farkındalık düzeyi ve yaşamı ile ilgili çok önemli bir bilgiye dikkat çekmektedir: “Atay'ın ölüme giden yolculuğunun başlangıcındaki 'fiziksel' belirtilerden çok daha önce, 'ruhsal' düzlemde kotarılarak kimi kez düşlerde ortaya çıkan, kimi kez önsezi ve esin denen bilinmezlerin birbirine harmanlanmasıyla kurmaca düzleme taşınan belirtiler; onun, erken yaştaki bu ölüm yolculuğundan ve yakalanacağı hastalıktan, rastlantının boyutlarını aşan bir gizemle derinlerde bir yerde haberdar olduğu izlenimini uyandırıyor. Cevat Çapan, Atay'ın metinlerinde yer alan, kendi ölümüyle ilgili önsezilerin, "onun gelecekten haber veren bir yazar niteliği taşımasına yol açtı [ğını], [g]eleceği bilen bir yazar, ölümünden haberli bir yazar gibi," algılanmasına neden olduğunu söylüyordur. Türk edebiyat eleştirisinin, ayakları somut gerçeğin üstünde duran, kurduğu yayınevinin ismini bile "Gerçek Yayınevi” koyan gerçekçi eleştirmeni Fethi Naci "Tutunamayanlar"da beynindeki ur nedeniyle ölen roman kişisinden söz ederken, her ne kadar önsezi yerine rastlantı sözcüğünü kullanıyor olsa da "çarpıldığını" söylemeden edemiyordur. "Size bir şey söyleyeyim: Öleceğini biliyordu; ölüme yakın olduğunu bilen biri gibi davranıyordu, 'hayat bu kadarmış' bir tavrı vardı”, diyordur, son dönemindeki yakın çevresinden, Bülent Korman.” (2017: 530)
} 
(Ellison, 2004: 15) gibi cümlelerle, zihinsel ve bedensel sürgünün hastalık belirtilerini gün yüzüne çıkarır. Farkındalık ve yabancılaşma sonucu ortaya çıkan ağrı, tıpkı Turgut gibi Görülmeyen Adam tarafından da 'beyne' vurgu yapılarak anlatılır. Boya fabrikasında çalıştığı esnada hastaneye kaldırılan anlatıcı baygın bir haldeyken kendisine uygulanması planlanan şok tedavisi ile ilgili şu konuşmalara tanık olur:

\begin{abstract}
Makine bıçağın negatif etkisi olmaksızın bir ön frontal lobotomi sonuçlarını verecek,” diyordu ses. "Anlıyorsun, ön frontal lobu zedelemeden, bir tek lob, yani ana sinir kontrol merkezlerine yeterli derecelerde basınç uygulayacağız - bizimkisi Gestalt ve anlayışsonuç, kişilikte tam bir değişim, tıpkı o ünlü peri masallarındaki, kanlı bir beyin ameliyatı işleminden sonra cana yakın insanlar hâline gelen caniler gibi. (Ellison, 2004: 223)
\end{abstract}

Turgut'un "Selimlik" (Atay, 2018: 362) yani yabancılaşma olarak, Görülmeyen Adamı'n da egemen toplum yapısını 'canilik' olarak tanımladığı düzende, karakterler toplumsal yapının başarılı bir okumasını yaparlar. Her iki eserde de ilk bakışta negatif bir kavram olarak ortaya çıkan yabancılaşma, karakterler tarafindan pozitif bir duruma dönüştürülerek aşılacaktır.

\title{
Köle'nin Başkaldırısı: Egemen Toplumsal Yapının Yerinden Edilmesi
}

Değişmek, kendine yabancılaşmak demekti.

(Atay, 2018: 319)

Turgut, Selim ve Görülmeyen Adam'ın hikâyelerinde 'köleleştirilme' ortak bir izlektir. ${ }^{16}$ Görülmeyen Adam'ın serüveninde, Amerikan toplum yapısında köleleştirilen siyahi Amerikalıların tarihsel deneyimi sembolik anlamda değil gerçek anlamda köleliği ifade etmektedir. Dolayısıyla efendi-köle ilişkisi sosyal yaşamda var olan bir durumdur. Hikâyedeki bir yaşlı kadın ile sohbeti esnasında anlatıcı buna vurgu yapar: "Efendimi çok sevdim ben oğul" dedi,"(Ellison, 2004: 14) "Ben de gülerim; ama ağlarım da. Bizi özgür bırakacağına söz verdi; ama bir türlü eli varmadı buna. Onu yine de seviyordum." (Ellison, 2004: 14) Siyahiler için geçerli olan kölelik, Görülmeyen Adam'ın kendisi için sembolik anlamda geçerlidir. Hikâyesini anlatırken o fiziken bir köle değildir belki fakat sistem tarafından yabancılaştırılan ve ötekileştirilen birey olarak modern dünyanın yeni kölesi hâline gelmiştir. Tutunamayanlar'da da kölelik ana karakter için kaçınılmaz bir durumdur. Turgut kendi dünyasının bir yansıması olan Selim için: "Esir, Selim, esir," (Atay, 2018: 29) "Zavallı Selim, zavallı Selim" (Atay, 2018: 129) serzenişi ile Selim'in toplumsal düzen tarafından köleleştirilerek her şeye yabancılaştırılmasına vurgu yapar. Hikâyelerinin ilk bölümlerinde karakterler sistem tarafından prangalanan ve hiçbir özgürlük alanları olmadan zihinsel ve bedensel sürgüne mahkûm edilen sembolik kölelerdir. Bu köle olma hâli, yabancılaşma hâllerinin ana kaynağıdır. Selim ve Turgut için toplum tarafından 'anormal' damgası yiyerek dışlanmaları efendi-köle ilişkilerini tanımlarken, Görülmeyen Adam'ın ten renginden dolayı ömrünün sonuna kadar 'köle' imajına mahkûm edilmesi efendisinin ona vurduğu prangadır. Her ne kadar karakterler çaresiz görünseler de mahkûmiyetlerini tersine çevirir, sistemi sessizce deler ve kendilerine has bir yol bularak köleliklerinden özgürleşirler. ${ }^{17}$ Birer anti-kahraman olarak da okunabilecek olan Turgut ve Görülmeyen Adam

\footnotetext{
${ }^{16}$ Eserlerin karşılaştırmalı edebiyat verileri ışı̆̆ında incelenmesi sürecinde 'yabancılaşma' büyük izlek iken 'kölelik' ikincil izlek olarak tanımlanabilir. Cemal Sakallı'nın ifade ettiği gibi “[i]zlek, genel olarak 'yazının dışında' yaşanmış ve yazarın yazınlaştırmasını özendirmiş bir olgu, haber, olay, yaşantı ya da başka bir yazınsal yapıt olabilir. Bir yönüyle izlek, belli kişi, yer, zaman ve onlara eşlik eden durumlara bağlı olarak yaşanmış, biçimlenmiş, yazınsal olarak anlatılabilir, biçimlendirilebilir ya da yazının nesnesidir." (Sakallı 2006: 173) Her iki eserde de toplumsal 'kölelik' izlek olarak yazarları eserlerini oluşturmada özendirmiş olabilir.

17 Selim, Turgut ve Görülmeyen Adam topluma başkaldıran tavırları ile flanör tipler olarak da okunabilirler. Egemen yapının dayattıklarını kabul etmenin normal sayıldığı düzende, anormal görülme pahasına kendi bildikleri yoldan giderler. Köksal Alver'e göre: “Flanör, modern kent hayatının önemli figürlerinden biridir. Modernite ile var olan bir sosyal tiptir. Kentsel toplumun, tüketim toplumunun, modern ilişkilerin ortasında yer almaktadır. Cadde, sokak, bulvar, pasaj, vitrin gibi mekânların içindedir. Bu mekânlardaki nesnelerle, insanlarla içli dışlıdır, onlarla iletişim halindedir. Kalabalıkla beraberdir, kalabalıklarda kaybolmaktadır, kalabalıktan beslenmektedir. Ama yalnızdır, kendi başınadır; çünkü aynı zamanda kendi
} 
“...marjinal, aciz ve yenik de olsalar egemen değerleri tersyüz eden, bu değerleri oluşturan siyasi ve ideolojik yapıları irdeleyip yadsıyan ve aynı anda da estetik alanın sınırlarını zorlayan..."(Parla, 2015:7) yapıları itibariyle, kendilerine dayatılan yabancılaşmadan özgürleşmeyi başaracaklardır.

Turgut ve Görülmeyen Adam'ın yabancılaşma sürecinden özgürleşmesi Hegel üzerinden okunabilir. Turgut Özben, "Değişmek, kendine yabancılaşmak demekti”(Atay, 2018:319) sözleriyle değişebilmek ve ruhsal gelişimini tamamlayabilmek için yabancılaşmanın kaçınılmaz olduğunun bilincindedir. Turgut, "Turgut Özben'in öz benliği. Kelime oyunu yapıyorum, oyuna getiriyorum. Kendimi ele vermiyorum" (Atay, 2018: 323) ifadesiyle öz benliğine ulaşmak için bilinçli olarak sessizce ilerlediğini fakat özgürleşme yolunda olduğunu anlatır. Görülmeyen Adam'da yabancılaşma sürecini ruhunu geliştirebilme firsatına dönüştürür. "Görülmezlik öncesi” (Ellison, 2004: 21) ifadesiyle, görülememe yani yabancılaşma hâlinden çoktan çıktığını ve yabancılaşmış benliğinin üstesinden gelerek kendine dönmeyi başardığının altını çizer. Turgut, kendini ele vermez ve sessizce yoluna devam ederken Görülmeyen Adam da inindeki sessizliktedir fakat tıpk1 Hegel'in yabancılaşmış bireyi gibi doğaları gereği aslında her daim hazırda bekleyen bir başkaldırma içgüdüsünü de özlerinde barındırmaktadırlar. Hegel'in Tinin Görüngübilimi'nde yabancılaşmanın yabancılaşması olarak tanımladığı bu durumda:

\begin{abstract}
Özbilinç için önünde bir başka özbilinç vardır; kendi dışına çıkmıștır. Bunun iki anlamı vardır: Illkin, kendi kendisini yitirmiștir çünkü kendini başka bir öz olarak bulur; ikincisi bu yolla başkasını ortadan kaldırmıştır çünkü başkasına öz olarak bakmaz, tersine başkasında kendi kendini görür ....kendi kendisini ortadan kaldırma yoluna gider. (Hegel, 2015: 80-81)
\end{abstract}

$\mathrm{Bu}$ devrimsel başkaldırı sürecinde, Turgut kaybolarak, Görülmeyen Adam in olarak tanımladığı odasında ölü gibi yaşayarak kendi kendilerini yok ederler. Her ikisi için de yabancılaşan öz benlikleri yani “...içinde kendini tanımadığı şey bundan böyle ölü bir zorunluluk değil, tersine evrensel bireysellik yoluyla diriltilen zorunluluktur."(Hegel, 2015: 152) Turgut ve Görülmeyen Adam da yabancılaşma durumlarının üstesinden gelerek pasif bir direniş ile sistemi delerler. $\mathrm{Bu}$ durum "kişiliğin yabancılaşmasıdır" (Hegel 2015: 196) ve "kendisinin dışlanması" (Hegel, 2015: 196) hâlidir. Dolayısı ile köleleştirilmeye karşı sergilenen bu devrimci başkaldırı Hegel'e göre tüm kültür dünyasının gerçek var olan tinidir (Hegel 2015: 198) ve mücadelelerinde efendilerine karşı en önemli silahlar1 olacaktır.

Turgut ve Görülmeyen Adam öncelikle egemen toplum yapısından, efendilerinin onları yabancılaştırarak köleleştirdiği süreçten çıkmayı başararak özgürleşirler. İkinci adımda ise toplumsal olarak görülememeyi, hiçbir yere tutunamamayı yani sembolik bir ölümü kabule geçerek köleliklerinden özgürleşeceklerdir. "Hegel'e göre insan olmak, ölebilmek ve ölmeyi bilmek demektir. Demek ki, insanın gerçek (hakiki) varlı̆̆ı, son çözümlemede, bilinçli fenomen olarak kendi ölümüdür.”(Kojeve, 2001: 156) Ana karakterler de adeta kendilerini öldürerek hedeflerine ilerlerler. Görülmeyen Adam artık bir inde yaşamaktadır ve adeta bir ölü sayılmaktadır, inini "mezar kadar rutubetli ve soğuk" (Ellison, 2004: 10) olarak tanımlayarak ölüme işaret eder. "Canlıdan çok ölü hissediyordum kendimi" (Ellison, 2004: 477) der. Selim ise intihar ederek ölüme gitmiştir. Turgut da farklı değildir, bedensel olarak yaşıyor olsa bile kaybolduğu için ölümüne hükmedilmiştir. Fakat

\footnotetext{
bireysel dünyasını örmektedir. Kendine güvenen, topluma eleştirel yaklaşan biridir. Kalabalıktan beslendiği halde ona sırtını dönebilendir. Modern hayatın en ilginç tiplerinden biri olan flanör, kentsel hayat ritüelleri, tüketim, boş zaman, kentlilik gibi sorunların konuşulması, tartışılması bakımından kayda değer bir tiptir. Modern kent hayatının kültürel açılımları açısından izlenmesi gereken biridir" (Alver, 2012: 286). "Bilinçli aylak' olarak ifade edilen flanör kavramı ilk kez Walter Benjamin'in Pasajlar adlı eserinde Charles Baudelaire ve kahramanları için kullanılmıştır. Bu yeni tip, Paris’ten başlayarak tüm Avrupa'ya yayılmıştır. Bu kavram,Türk Edebiyatı'nda da 20. yüzyılda önem kazanmıştır. Detaylı bilgi için bkz. Walter Benjamin. (2014). Pasajlar. (Ahmet Cemal, Çev.). Yapı Kredi Yayınları.
} 
bu ölümler bilinçli varlıklarına ulaşabilmek için bir stratejidir. Berna Moran, Atay’ın bu stratejisini şu şekilde açıklar:

Atay'ın tutunamayanları burjuva düzeninin kurallarına, değer yargılarına, beğenisine, yaşam biçimine ayak uyduramayan, topluma yabancılaşmış yalnız insanlardır. Yazar küçük burjuva aydınlarını silkelemek için onların kültür değerleriyle, ideolojik tutumlarıyla, yaşamda bağlandıkları konvansiyonlarla alay eder ama bununla yetinmez. Çünkü saldırı hedefi olan zihniyet sanat anlayışını da içerir ve bundan ötürü Atay saldırısını, tutunanların anlamayacağı reddedeceği türden bir romanla yapar...Tutunamayanlar hem söyledikleri hem de söyleyiş biçimiyle bir bașkaldırı[dır]. (Moran, 2016: 234)

Hikâyelerinde de Turgut ve Görülmeyen Adam, toplumun kölesi olarak özgürleşmeye adaydırlar çünkü düzene başkaldıracaklardır. Bu nedenledir ki, her ikisinin de başkaldırı eylemleri, varoluşçu bir tavır ile tüm tutunamayanlar ve görülmeyenler için bir adalet arayışı olacaktır. Kölelikten kurtulacaklarının ve efendinin onlara biçtiği giysileri giymeyeceklerinin sinyalini verirler. Turgut: "Bir biçim veremeyecekler bana," (Atay, 2018: 386) "Hiçbir geleneğin mirasçısı değilim" (Atay, 2018: 541) iddiasında bulunur. Görülmeyen Adam da: "Ben hiç kimse değil kendimdim. Ama önce görülmeyen bir adam olduğumu keşfetmem gerekmişti" (Ellison, 2004: 19) sözleriyle yabancılaşma sürecini tamamlaması ile efendiyi yenme potansiyeline ulaşacağının altını çizer çünkü düzene, bir köle olarak başkaldıracaktır. Turgut ve Görülmeyen Adam'ın başkaldırısı Albert Camus'un “Kimdir Başkaldıran insan?"(2014: 13) sorusunu akıllara getirmektedir. Camus'a göre başkaldıran insan 'hayır' diyebilen varlıktır. Bu 'hayır'ın' içeriği adeta bir varlık nedeni arama yolculuğunda olan bireyin haklı olma ve adalet duygusundan yola çıkarak 'buradan öteye geçiş yoktur' söyleminin ilanıdır. Bu noktadan itibaren hiçbir şey eskisi gibi olmayacaktır çünkü "umutsuzluk" (Camus, 2014: 14) ile başlayan hikaye tıpkı Turgut ve isimsiz kahramanda olduğu gibi, "devinim" (Camus, 2014: 14) ile yoluna devam edecektir. İçsel yolculuklarının başında sessizliğe gömülerek egemen toplum yapısının, efendinin, onlara dayattıklarını betimleyen Turgut ve Görülmeyen Adam “...daha önce bir uzlaşma içine yerleşmişken, birdenbire ("değil mi ki böyle...) ya Hep ya Hiç’in içine atılır. Bilinç başkaldırıyla doğar.'(Camus, 2014: 14). İlk bakışta ani bir eylem olarak görülse de 'başkaldırı' her iki karakterin de yabancılaşma süreçlerinin doğal bir parçasıdır ve "köle yalnızca kendisi için değil aynı zamanda tüm varlıklar için ayaklanır"(Camus, 2014: 15).

Tutunamayanlar' da Turgut, tüm tutunamayanlar için kendine sözde bir köle yaratır fakat bu köle, eziyet gören, zulüm edilen bir köle değildir. 'Olric' adındaki bu sözde köle iç benlik rolü üstlenir. Turgut, Olric ile köleliğinden arınır çünkü Tugut'u yazdığı takdirde gülünç duruma düşeceği korkusundan arındırarak yazmaya teşvik eder. Olric sayesinde Turgut, Tutunamayanlar'ı yazar. Eseri onun için efendi ile olan savaşını kazanmasına olanak sağlayacak bir silahtır: "Roman gelecek senin hakkından. Kendi silahınla gebereceksin"(Atay, 2018: 347) söylemi de bir bakıma bu durumu özetler. Görülmeyen Adam da tıpkı Turgut gibi köleliğinden sıyrılmış, efendinin kendi üzerindeki hükmünü yok etmiştir: "Yıllar önce (görülmez olmanın yararlarını keşfetmeden önce) ben de herkes gibi elektriklerini tüketir, dünyanın parasını öderdim onlara"(Ellison, 2004: 9) ifadesiyle tutsaklığının artık hükümsüz olduğunu beyan eder. İsimsiz kahraman, değişimi tamamlamış ve toplumsal yapının üzerinde kurduğu güçten kurtulmuştur ve bu özgürleşmeyi şu şekilde betimlemektedir: "Benim de öteki insanlar gibi görülür olduğum yanlış sanısına dayanıyordu bu yaşayış tarzı. Şimdi görülmezliğimin farkında, yalnızca beyazlara kiralanan bir evin bodrum katının on dokuzuncu yüzyılda kapatılmış ve unutulmuş bir bölümünde kira vermeden oturuyorum..." (Ellison, 2004: 9). Anlatıcı belirli bir bilinç düzeyine varmıştır ve "Bütün bunlar, artık ölmüş olan öteki yaşamın öyle bir parçasıydı ki, hiçbirini anımsamıyorum. (Zaman tıpkı bana benziyor; ama ne o zamanlar ne de o "ben" var artık)" (Ellison, 2004: 40) sözüyle tanımlar mevcut durumunu. Hegel felsefesindeki hakiki varlığına kendi ölümü ile ulaşan birey hâline gelmeyi başarmıştır. 
Turgut, kölesi Olric ile bir savaşa girer ve bu savaştan galip çıkarak ona şekil vermeye çalışan egemen yapıya izin vermeyerek yabancılaşmış benliğini yabancılaşmadan özgürleştirir ve efendi ile olan mücadelesinde galip gelir. Görülmeyen Adam da tıpkı Turgut gibi efendi ile olan savaşını kazanarak bilinçlenmiş, görünmezliğini kabuk ederek yabancılaşma sürecini sonlandırarak öz benliğine kavuşmuştur ve neredeyse imkânsız olan bir şeyi başararak yalnızca beyazlara kiralanan bir bodrum katında kira vermeden aylardır oturmaktadır. Karakterler, efendiyi tamamen ortadan kaldırmamışlardır. Beyaz ırkın gücü hüküm sürmektedir. Turgut için de burjuvanın dayattıkları hala geçerlidir fakat her ikisi de efendinin üzerlerinde kurduğu gücü geçersiz kılarak özgürleşirler ve efendi ile olan savaşlarındaki başarı umutlarını güçlü bir imge olan İsa Peygamber üzerinden anlatırlar. Tıpkı İsa gibi haksızlığa uğrayacak, efendi tarafından öldürülecek ama asla isyan etmeyerek tevekkülle ilerleyerek yeniden doğuşlarını ilan edeceklerdir. Bu süreçte sergiledikleri pasif direniş sistemi baş aşağı çevirmek için bir nevi strateji olacaktır. Turgut Özben'in ifadesiyle: “İsa’nın sözü: 'Kötülüğe karşı direnmeyeceksin' sözünden büyük bir ferahlık duyuyorum. İnsana gerçek hürriyeti bu 'direnmemek' kazandıracak gibi geliyor bana"' (Atay, 2018: 661). Görülmeyen Adam ise "yakınmıyorum, karşı geldiğim de yok" (Ellison, 2004: 7) der. Tıpkı Turgut gibi İsa’nın izinden gider. Bu sessiz direniş her ikisine de İsa gibi yeniden doğuşun kapısını aralayacaktır. Görülmeyen Adam bu yeniden doğuşu şu sözlerle ifade eder: "Şimdi aniden derin bir uykudan uyanmış gibiydim" (Ellison, 2004: 395). Onlar için ölüm, tıpkı İsa'nınki gibi sadece yeniden doğabilmek adına doğal bir yabancılaşma sürecidir ve bu süreç efendi ile olan savaşlarından galip gelme ile son bulacaktır.

\section{Yeniden Doğuşun - Umut Işığı'nın Tasviri: Evrensel bir İmge Olarak İsa Peygamber}

İsa Peygamber her iki eserde de ortak bir imgedir. Kolektif bilinci işaret eder ve öteki hakkında toplum tarafından yaratılan resmi irdeler. ${ }^{18}$ "İmge tanımı gereği, özellikle yazarın / sanatçının kendini ifade etmek için kullandığı bir araç olarak algılanır" (Ulağlı, 2018: 14). Onur Kula'nın ifadesiyle "çeşitli kültürlerde geçerli olan toplumsal ilişkileri düzenleyiş, insana bakış, sorunları algılayış, estetik beğeni, değerler dizgesi gibi alanları içerir" (Kula, 1992: 18). İki romanda da İsa Peygamber değerler dizgesi olarak önce pasif direniş, yabancılaşma, köleleştirilme, eziyet görmenin sembolik alanı olurken eserlerin ilerleyen bölümlerinde yeniden doğuş, umut 1şığı, kurtuluş, bütünleşme ve huzura erme hâlini betimler. Aynı zamanda "kardeşlik" kavramının sembolü hâline gelerek tüm "tutunamayanların” ve "görülmeyenlerin" ortak sesi olur. Y1ldız Ecevit'in ifadesiyle:

Bu pasif direnişte tutunamayanların en büyük destekçisi ise göksel sistemden bir varlıktır: İsa Peygamber Atay'ın "[B]ir yanağını vurana öbürünü de çevir[en]”, kötülüğe direnmeyen eylemsiz tavrıyla İsa'yı bir tutunamayan olarak kabul ettiği ve diğer göksel kişilerden kendine daha yakın bulduğu söylenebilir. Yerleşik düzenin karşıt erdemleriyle, gösterişsiz ve çıkar gözetmez tutumuyla bir tutunamayan arketipidir o. İsa metinde; Hamlet, Don Kişot, Oblomov gibi kurmaca dünyadan mitik kahramanlarla birlikte, roman kişilerinin çevresinde oluşturulmak istenen imge ağının düğümlerinden biridir; dinsel bağlamda kutsal bir kimlik olarak yer almaz. Atay, İsa'nın kutsal yönünü, roman kişisi Selim'in dünyasallıktan uzak özelliğine mistik bir vurgu katmak için kullanır: İsa metinde Hristiyan ideolojisinin bayrağı olmayıp, daha çok bir kurgu ögesidir. (Ecevit, 2017: 29495)

Görülmeyen Adam'ın hikâyesinde de İsa, bir kurgu öğesi olarak, 1şığın ve kurtuluşun sembolüdür: "Dünyayı da istemiyorlar, yalnızca İsa'yı istiyorlar. Yalnızca İsa'yı istiyorlar, yalnız on beş dakika, çulu çaputu alınmış bir odada İsa'yı. Ne dersiniz Bay Kanun? On beş dakikalık İsa'mızı alabilir miyiz? Siz, dünyayı almışsınız, biz de İsa'mızı alabilir miyiz?” (Ellison, 2004: 262) çağrısında

\footnotetext{
18 İmgebilim “[k]imlik sorunlarına 1şık tutan...farklı disiplinler arasında köprü kuran bir bilim dalıdır” (Burçoğlu, 2005: 106) aynı zamanda "kalıp imgeleri/streotipleri inceleyen karşılaştırmalı edebiyat biliminin bir dalı" olarak tanımlamaktadır." (İldem, 2000: 21)
}

Turkish Studies - Language, 15(3) 
bulunur siyahi Amerikalılar. Kurtuluşun sembolü olarak İsa, yalnızca Görülmeyen Adam'ın değil tüm siyahi Amerikalıların umut 1şı̆̆ıdır. New York'a sürgün edildiği ilk günlerde çaresizlik içerisinde yabancılaştırıldığı dünyada bir başına kalmışken tek sığınağı İncil dolayısıyla İsa'nın hikâyesidir. “...etrafımda tanıdık hiçbir şey de yoktu. İncil'den başka; İncil'i kaptım ve yeniden yatağa oturdum, kan kırmızı kenarlı sayfalarını başparmağımla taradım” (Ellison, 2004: 155) sözleriyle tutunduğu ve kendine yakın hissederek görülür olduğu tek alanın İsa'nın hikâyesi olduğunun altını çizer. Turgut Özben için de durum aynıdır. Sı ğındığı limandır İsa'nın hikâyesi: "Durmadan İncil okudu. Can sıkıntısıyla günler geçti. Sonunda dayanamadı İsa'ya bir mektup yazdı" (Atay, 2018: 154) bilgisini verir okuyucuya. İsa, tıpkı Turgut gibi Görülmeyen Adam için de ışığı̀n dolayısıyla aydınlığa kavuşmanın ve kurtuluşa ermenin imgesi olarak "zihinsel bir yansıma[dır]"'(Bülbül, 2005: 14). "Ve kafam, teselli arıyor, bahar akşamının alacakaranlığından ve çiçek kokularından uzaklara, çarmıha gerilişin zaman-sahnesinden doğumun zaman-havasına kaçarak, akşam duasından yüksek, parlak ve aydınlık kış ayına kaçarak; ve kar, çanların yerine..." (Ellison, 2004: 106) derken karanlıktan aydınlığa ulaşma hikâyesini yine İsa üzerinden anlatır. "Işıktan yalnızca kiliselerde değil, günün büyüleyiciliğini kutsayan dinsel törenlerde de söz edilir..." (Sivri, 2008: 25) ve elbette "Işığın ve parıltının rengi beyaz, hayra alametin işaretidir." (Sivri, 2008: $28)^{19}$ İsa da, Görülmeyen Adam için umut 1şı̆̆ıdır çünkü ona göre "Hakikat 1şıktır, 1şıksa hakikat" (Ellison, 2004: 11) ve kurtuluşa giden yolda aydınlanma, İsa'nın göğe yükselişi gibi pozitif bir durumdur. Bu yüzden de "Ve ışığı çok seviyorum. Görülmeyen bir adamın ışığa ihtiyacı olmasını, ışık arzu etmesini, ışığa âşık olmasını garip bulacaksınız belki de. Ama kim bilir, belki de görülmez olduğum için böyledir bu. Işık, gerçekliğimi doğruluyor benim, biçimimi ortaya çıkarıyor" (Ellison, 2004: 10) ifadesini kullanır. ${ }^{20}$ Görülmeyen Adam için 1şı̆̆ın ve aydınlanmanın sembolü olan İsa, Tutunamayanlar'da o kadar güçlü bir imgedir ki Selim'in soyadı "Işık'tır." Yıldız Ecevit'in ifade ettiği gibi:

Tutunamayanların soyut özelliklerle donatılmış, bir çocuk kadar saf ve temiz önderi Selim Işıłk'la İsa arasında kurulmak istenen koşutluk, onun soyadında vurgu kazanır. İncil'de İsa'nın 1şık olduğu birçok yerde vurgulanır: "[T]üm insanları aydınlığa kavuşturmak için dünyaya gelen Işık[tır]" İsa. Atay'ın İncil'i üzerinde durarak okuduğu, kuracağı imge ağını göz önünde bulundurarak Iş̧ı soyadını verdiği su götürmez (2017: 295)

ve yalnızlığın, yabancılaşmanın sembolü olan Tutunamayanların örnek aldığı isim Selim Işsk da, İsa üzerinden anlatılır. Öldürülen, zulüm gören, eziyet çeken, sürgün edilen ama dönüşü beklenen umut ışığıdır Selim, tıpkı İsa gibi. Görülmeyen Adam nasıl İncil'e, İsa'nın hikâyesine tutunuyorsa, Turgut da benzer şekilde davranır. Sürekli olarak İncil okur (Atay, 2018: 154). Selim Işık'ın ölümünü de öldürülen İsa'ya benzetir. Haksızlığa uğramışlığını "Onu bir kere öldürdünüz...Birinci ölümünden temizleyeceğim onu, ikinci gelişini sağlayacağım böylece"( Atay, 2018: 417) diyerek anlatır. Selim mektupları aracılığı ile âşık olduğu kadın Günseli'ye uğradığında, ki Günseli'de Selim'den türetilmiş, güneşi dolayısı ile 1şığı çağrıştırandır, "İsa'ya benzeyip benzemediğimi sordum ona" (Atay, 2018: 599) bilgisini okuyucu ile paylaşır. Tutunamayarak göğe yükselen İsa, Selim Işık'ın ta kendisidir. Tutunamayanlar için Selim ve İsa izinden gittikleri iki önemli rol modeldir. Kimi zaman

\footnotetext{
${ }^{19}$ Edebiyatta renk sembolizmi ile ilgili kapsamlı bir çalışma için bkz. Medine Sivri (2008). Paul Eluard ve Nazım Hikmet'te Renklerin Dili. Kanguru.

${ }^{20}$ Ralph Ellison, Paris Review dergisine verdiği bir röportajda romanın baş karakterinin gelişim sürecini karanlıktan 1şığa doğru dolayısı ile cehaletten farkındalığa, aydınlanmaya giden bir yol olarak tanımlar. Romanın sonunda Görülmeyen Adam'ın ininden çıkmasını da bu durumu açıklamada bir örnek olarak gösterir (akt. Callahan, 2004: 41).İki eseri birbirine bağlayan bir başka ortak nokta ise Turgut ve Görülmeyen Adam'ın kendilerini bulma serüvenlerinin Bildungsroman, Türkçe'ye genel olarak “oluşum romanı” olarak çevrilen, türün örneği olmalarıdır. Kökeni Alman Edebiyatı'na dayanan bu tür, bireyin ideal hâline ulaşma sürecinde deneyimlediklerini aktarır. Turgut ve Görülmeyen Adam'ın da efendi ile olan mücadelelerindeki evirilme süreçleri bunu başarıyla yansıtmaktadır. Detaylı bilgi için bkz. Petru Golban (2018). A History of the Bildungsroman. From Ancient Beginnings to Romanticism. Cambridge Scholars Publishing.
} 
İsa'ya mektup yazar ve anneleri evde yokken gelmesini ve rahat rahat konuşabileceklerini iletir. Kimi zaman Tanrı'ya yakararak İsa ve Selim'in ikinci gelişlerinde yalnız bırakılmamaları ve bir arada olmaları için dua eder. İsa, Turgut Özben için gelişi dört gözle beklenen umut 1şı̆̆ıdır. Dolayısı ile "İsa imgesi, romanın çokkatmanlı dokusunun içinde tüm katmanları birbirine bağlayan bir katalizör madde görünümündeki "tutunamamak" motifine eşlik eder, onun anlamını zenginleştirir." (Ecevit, 2017: 296) Elif Şafak, Atay’ın bir imge olarak İsa’yı seçmesini şu sözlerle açıklar:

Bana ilginç gelen -ve tabii bu çok yoruma açık bir şey- bir başka unsur, o dönemin eleştirmenleri tarafından dile getirilmiş. Mesela Tutunamayanlar'daki Selim karakterinin niye İncil okuduğu veya niye Hazreti İsa'yı bir rol modeli olarak ele aldığı sorgulanmış, Müslüman bir Türk aydının niye böyle bir referansı var diye... Halbuki ben orada tasavvufi bir okuma yapabileceğini düşünüyorum. Az evvel içe dönüklükten, yani kendi içini etkinleştirmekten bahsettim. Tasavvufta bildiğimiz gibi Hazreti İsa bir makamdır. Tıpkı Hazreti Musa'nın bir makamı olduğu gibi. Ve İsa'nınki son derece içe dönük bir makamdır aslında. Böyle baktığım zaman ben, Selim'in Tutunamayanlar'daki içe dönüklük vurgusuyla Hazreti İsa'yı rol modeli olarak almasında aslında bir tutarlılık olduğunu düşünüyorum. (2018: 114-5)

Tutunamayanlar'da Atay'ın isa'yı güçlü bir imge olarak okuyucu ile buluşturması metne anlamlı bir katk1 sağlamakta ve karakterlerin yabancılaşma serüvenlerine 1şı tutmaktadır. İki eserde de İsa bir imge olarak, karakterler için yeniden doğuşu deneyimlemede son derece önemlidir.

Karakterlerin, egemen toplum yapısı tarafindan yabancılaştırılarak başlayan hikâyeleri, yabancılaşmalarının ve efendi-köle diyalektiğinin doğasında var olan başkaldırı ve özgürleşme ile son bulur. Görülmeyen Adam sistemi stratejik olarak çözmüştür. Hikâyesinin girişinde "Önceleri, sürülmüş olduğum karanlıkta yaşıyordum; ama şimdi görüyorum. Görülmezliğimin karanlığını aydınlattım..."(Ellison, 2004: 17) ifadesiyle özgürleşmenin onun için çoktan tamamlandığı bilgisini verir. Öte yandan hikâyesinin sonunda "Eski derimi silkeleyip atıyorum, burada inimde birakacağım onu. Dışarıya çıkıyorum...” (Ellison, 2004: 544) açıklamasıyla öz benliğine ulaşarak efendinin ona dayattığı deriden kurtulmuş olma hâlini anlatır. Varlığını tescillemek için dışarı çıkarak sosyal yaşama dâhil olacağı sinyalini verir. $\mathrm{O}$, yalnızca siyahi Amerikalıların değil tüm görülemeyenlerin sesidir, bu nedenle de okuyucu ile vedalaşırken “...kim bilir, düşük frekanslarda, sizin adınıza konuşuyorumdur belki de?’(Ellison, 2004: 544) ifadesiyle tüm insanlığı kucaklar. Turgut Özben ise hikâyesinin sonunda tıpkı Görülmeyen Adam gibi köleliğinden özgürleşmiştir. "Herkesin istediği gibi yaşadığı o uzak ülkenin özlemini duyuyorum. Belki de bu ülke çok yakın" (Atay, 2018: 669) sözleriyle başarısının altını çizer ve yargıçlardan kabulünü rica ederek davasının sonuna gelir. Okuyucuya “Bir mayıs günü, arkadaşı Selim Işık'ın hayattan kendi arzusu ile ayrılması üzerine onun yerine geçti" (Atay, 2018: 722) sözüyle veda etmeye hazırlanır. Turgut "Tutunamayanlar Ansiklopedisi'ne" girmeye hak kazanmıştır. İsa ve Selim gibi yeniden doğuşunu tamamlayacaktır.

\section{Sonuc}

Farklı zaman dilimlerinde, farklı toplumlardan okuyucuya seslenen Tutunamayanlar ve Görülmeyen Adam eserleri, Türk ve Amerikan toplumunda yabancılaşma durumu ile karşı karşıya kalan ve bunun üstesinden gelmek için kendilerine has yöntemler yaratan karakterlerin hikâyeleridir. Her iki eserde de yabancılaşma teması ortaktır. Türk toplumundaki yabancılaşmış bireyi yansıtmak için Atay "tutunamayanlar" motifi ile bu durumu açıklarken, Ellison isimsiz kahramanının yabancılaşma sürecini "görülmemek" motifi üzerinden aydınlatır. Türk toplumunda zihinsel bir sürgüne mahkûm edilen karakterler, Amerikan toplumunda bedensel bir sürgün ile ten renklerine dayalı bir ayırımcılık ile karşı karşıya kalır. Toplumsal farklılıklar sebebi ile yabancılaşma hâli iki eserde farklı köklere dayansa da karakterler yabancılaşmayı deneyimleyen tüm bireylerin sembolü hâline gelir. "Görülmemek" ve "tutunamamak" motifleri yabancılaşma kavramını yansıtmada toplumlarüstü bir anlam kazanarak evrenselleşir. Eserlerin birinci evresi olarak tanımlanabilecek olan yabancılaşma hâlinde, Turgut Özben ve Görülmeyen Adam hapsoldukları sistemi okuyucu ile 
paylaşır. Bu evrede, karşılaştırmalı edebiyat bilimi verileri ışı̆̆ında incelenen yabancılaşma izleği her iki eserde de baş karakterlerin, kendilerine, topluma ve öz benliklerine yabancılaşmaları süreçlerindeki benzerlikleri ve farklılıkları açığa çıkarmaktadır. Eserlerin ikinci evresi olarak adlandırılabilecek olan faz da ise her iki eserde de baş karakterler yabancılaşma girdabından kurtulabilmek için çeşitli stratejiler geliştirirler. Bu durum, Hegel'in yabancılaşma kavramı ve köleefendi diyalektiği üzerinden incelendiğinde, Turgut ve Görülmeyen Adam'ın pasif direnişleri ile kendilerine has bir strateji belirleyerek yabancılaşmış beden ve zihinlerinden kurtuldukları görülmektedir. Karakterler efendi ile olan mücadelelerinde kendilerine biçilen tutunamama ve görülmeme durumlarını feshederler. Her iki eserde de bu galip gelme süreci göksel bir varlık olan İsa imgesi üzerinden umut 1şığı, yeniden doğuş, kurtuluş ve sürgünün sona ermesi gibi imgeler ağı üzerinden anlatılır.

Ele alınan eserlerin benzerlik ve farklılıklarının karşılaştırmalı edebiyat, izlekbilim verileri ve Hegel'in yabancilaşma ve köle-efendi diyalektiği ile eklektik bir yöntemle ortaya konmaya çalışıldığ 1 bu çalışma göstermiştir ki "tutunamamak" ve "görülmemek" motifleri yabancılaşma izleğini tanımlamada farklı toplumlardan okuyucuya seslenen eserler için ortak bir alan olmuştur. Türk ve Amerikan toplumunda yabancılaşmanın pençesine düşen baş karakterler hikâyelerine bu izlek yolu ile ışık tutmaktadır.

\section{Öneriler}

Atay, Tutunamayalar romanı ile ulusal filoloji alanında ezber bozan bir esere imza atmıştır. Alışılmışın dışına çıkan kurgusu ile Tutunamayanlar adeta Türk edebiyatının genetik yapısını değişime uğratmış, okura ve yazara bambaşka bir dünyanın kapısını aralamıştır. Yaşadığı dönemde arzu ettiği ilgiyle karşılaşamasa da eserleri ve özellikle Tutunamayanlar romanı Türk edebiyatı adına bir mihenk taşı haline gelmiştir. Atay ile ilgili sorun da tam da bu noktada cereyan etmektedir. Bir tarafta hayatta olduğu dönemde kayıtsızlığın ve dışlanmanın içine hapsedilen Atay, bir diğer tarafta da muazzam eserleri ile, özellikle Tutunamayanlar romanı ile, adeta ilahlaştırılarak dokunulmaz bir alana hapsedilen Atay. Her ne kadar ikincisi pozitif bir yaklaşım gibi incelenebilecek olsa da, Atay'1 adeta sırça bir fanusun içine hapsederek korumaya almak son derece tehlikeli bir eylemdir. Bu tutum, Atay'ı ulusal filolojinin sınırları içerisine hapsederek eserlerinin farklı kültürlere ait eserler ile buluşmasına ve özellikle Tutunamayanlar'ın akademik anlamda ulusal filoloji dışında daha fazla çalışmaya alan olmasına engel olmaktadır. Atay'ı ulaşılmaz bir alanın merkezine yerleştirmek onu ve eserlerini yalnızlaştırmaktan bir adım öteye gitmemektedir ki bu yalnızlık ve bir nevi görmezden gelinme hissi Atay'ın yaşamı süresince en fazla incindiği konudur. Bu yüzdendir ki bu muazzam eseri tartışılamaz, dokunulamaz ve karşılaştırılamaz alanının dışına çıkararak karşılaş̧ırmalı edebiyat bilimi verileri ışığında incelemenin Tutunamayanlar romanının zamanın ve mekanın dışına taşan enerjisine katkı sağlayacağı kanısındayım. Bu açıdan bakıldığında Atay'ın eserlerinin doğası gereği genlerinde hoşgörüyü ve ötekini anlamayı barındıran karşılaştırmalı edebiyat bilimi verileri ışı̆̆ında incelenmesinin ulusal filolojiye önemli katkılar sağlayarak uluslararası platformda eserlerimizin sesini duyulur hale getirebileceği düşüncesindeyim.

\section{Kaynakça}

Adorno, T. W. \& Horkheimer, M. (2010). Aydınlanmanın Diyalektiği: Felsefi Fragmanlar. (Nihat Ülner \& Elif Karadoğan, Çev.). Kabalcı Yayınları.

Alver, K. (2014). Flaneur: A Modern Urban Figure / Flanör: Bir modern kent Figürü. Akademik Incelemeler Dergisi. 7 (2), (ss. 285-293).

Aktulum, K. (1999). Metinlerarası İlişkiler. Öteki Yayınları.

Aktulum, K. (2011). Metinlerarasılık / Göstergelerarasılık. Kanguru Yayınları. 
Andaç, F. (1996). Sürgün Edebiyatı, Edebiyat Sürgünleri. Bağlam.

Arnold, M. (1857). On The Modern Element In Literature.

(https://tr.scribd.com/doc/11554174/Matthew-Arnold-On-the-Modern-Element-inLiterature. Web. 23 March 2020)

Atalay, İ. (2019). Karşılaştırmalı Edebiyat. Hiper.

Atay, O. (2018). Tutunamayanlar. Bütün Eserleri I. İletişim.

Aytaç, G. (2019). Karşılaştırmalı Edebiyat Bilimi. Doğu Batı.

Baptist, E. E. (2016). The Half Has Never Been Told. Slavery and Making of American Capitalism. Basic Books.

Benjamin, W. (2014). Pasajlar. (Ahmet Cemal, Çev.). Yapı Kredi Yayınları.

Bumin, T. (2019). Hegel. Bilinç Problemi, Köle Efendi Diyalektiği, Praksis Felsefesi. Yapı Kredi Yayınları.

Burçoğlu, N. D. (2005). Disiplinlerarası Bir Bilim Dalı Olarak İmgebilim, Edebiyat ve Eleştiri, 81, 105-107.

Bülbül, M. (2005). Imgesel İletişim. Çizgi.

Callahan, J. F. (Ed.). (2004). After Publication. Ralph Ellison's Invisible Man: A Casebook (ss. 3541). Oxford University Press.

Camus, A. (2014). Başkaldıran İnsan. E-kitap (Tahsin Yücel, Çev.). Can Yayınları. https://books.google.com.tr

Cuma, A. (Der.). (2019). Genel ve Karşılaştırmalı Edebiyat Çalışmaları. Çizgi.

Cevizci. A. (2000). Paradigma Felsefe Sözlüğ̈̈̈. Paradigma Yayınları.

Du Bois, W. E. B. (1994). The Souls of Black Folk. Dover Publications.

Ecevit, Y. (2017). Ben Buradayım.Oğuz Atay'ın Biyografik ve Kurmaca Dünyası. İletişim.

Ellison, R. (2004). Görülmeyen Adam. (Mehmet H. Doğan, Çev). İletişim.

Eyüboğlu, İ. Z. (1995). Türk Dilinin Etimolojik Sözlüğ̈̈. 3. Basım. Sosyal Yayınlar.

Fromm, E. (2017). Olma Sanatı (Orhan Düz, Çev.). Say Yayınları.

Golban, P. (2018). A History of the Bildungsroman. From Ancient Beginnings to Romanticism. Cambridge Scholars Publishing.

Güven, D. Ç. (2020). Foucauldian "Medical Gaze" as an Ideological Apparatus of Modern Power Structures in the Works of Rifat Ilgaz, Ōoka Shōhei, Jean-Paul Sartre and Joseph Conrad. Folklor/Edebiyat, 26 (101), 157-171.

Hegel, G. W. F. (1976). Bütün Yapttları, Seçmeler 1. (Hüseyin Demirhan, Çev.). Onur Yayınları.

Hegel, G. W. F. (2006). Tarih Felsefesi. (Aziz Yardımlı, Çev.). İdea.

Hegel, G.W.F. (2015). Tinin Görüngübilimi. (Aziz Yardımlı, Çev.). İdea.

Inwood, M. (1992). Hegel Dictionary. Blackwell Publishers.

İldem, A. E. (2000). Fransız Gezginlerin Gözüyle Türkler ve Yunanlılar. Boyut.

Kefeli, E. (2000). Karşılaşstırmalı Edebiyat İncelemeleri. Kitabevi Yayınları. 
Klein, M. (1964). After alienation: American novels in mid-century. Books for Libraries Press.

Kolchin, P. (2003) American Slavery. 1619 - 1877. Hill and Wang.

Kojeve, A. (2001). Hegel Felsefesine Giriş. (Selahattin Hilav, Çev.). Yapı Kredi Yayınları.

Kula, O. B. (1992). Alman Kültüründe Türk Imgesi, I. Cilt. Gündoğan.

Mizruchi, E. (1973). An Introduction to the Notion of Alienation. Frank Johnson (Ed.), Alienation: Concept, Term and Meanings (ss. 111-24). Seminar Press.

Moran, B. (2016). Türk Romanına Eleştirel Bir Bakış. Sebahattin Ali'den Yusuf Atılgan'a. İletişim.

Ollman, B. (2015). Marx'ın Kapitalist toplumdaki İnsan Anlayışı. (Ayşegül Kars, Çev.). Yordam Yayınları.

Osho. (2004). Farkındalık. (Amrit Sangeet, Çev.). Ovvo.

Parla, J. (2015). Türk Romanında Yazar ve Başkalaşım. İletişim.

Putz, M. (1979). The story of identity: American fiction of the sixties. Metzler.

Remak, H. (1961). Comparative Literature, Its Definition and Function. Stalknecht N. \& Frenz H. (Eds.), Comparative Literature: Method and Perspective (ss. 3-38). Southern Illinois Press.

Şafak, E. (2018). Oğuz Atay'ın Çocukları. İnci, H. ve Türker, E. (Ed.), Oğuz Atay İçin Bir Sempozyum (ss. 109-119). İletişim.

Sakallı, C. (2006). Karşılaştırmalı Yazınbilim ve Yazınlararasılık/Sanatlararasılık Üzerine. Seçkin.

Sayers, S. (2003). Creative Activity and Alienation in Hegel and Marx, Historical Materialism, 11 (1), 107-128.

Schacht, R. (1989). Social Structure, Social Alienation and Social Change. Schweitzer, D. \& Geyer, R. F. (Der.), Alienation Theories and De-Alienation Strategies (ss. 35-56). Science Review Ltd.

Seeman, M. (1959). On the meanning of alienation. American Sociological Review. 24 (6), 783-791. (https://www.jstor.org/stable/2088565?readnow=1\&seq=1\#page_scan_tab_contents)

Sivri, M. (2008). Paul Eluard ve Nazım Hikmet'te Renklerin Dili. Kanguru.

Ulağl1, S. (2018). Öteki'nin Bilimine Giriş. Imgebilim. Motto.

Wilkinson, R. \& Pickett, K. (2011). The Spirit level. Why Greater Equality Makes Society Stronger. Bloomsbury. 